Original article

\title{
2 Parametreli Lojistik Modelde Normal Dağılım İhlalinin Madde Parametre Kestirimine Etkisinin İncelenmesi
}

\section{Investigation of the Effect of Different Ability Distributions on Item Parameter Estimation Under Two-Parameter Logistics Model}

\author{
İbrahim Alper Köse (D) ${ }^{\text {a, * }}$ \& İsmail Başaran (1) b \\ ${ }^{a}$ Department of Educational Sciences, Faculty of Education, Bolu Abant İzzet Baysal University, Bolu, Turkey \\ ${ }^{\mathrm{b}}$ Ministry of Education, Turkey
}

\section{Özet}

Eğitimde ve Psikolojide ikili puanlanan maddelerden oluşan testler sıklıkla kullanılmaktadır. Madde tepki kuramı altında lojistik modellerle kullanılabilen bu testlerin madde parametreleri kestirilirken kestirimlerin daha keskin olmasını sağlayan bazı özellikler vardır ancak testlerin uygulandığı gruplar bu özellikleri her zaman sağlayamayabilir. Bu araştırmanın amacı, ikili puanlanan maddelerden oluşan bir veri setinin 2 parametreli lojistik (2PL) model ile analizinde veri setinin çeşitli özelliklerinin parametre kestirimlerinin keskinliğine olan etkilerini incelemektir. Bu araştırma, ikili puanlanan testlerden elde edilen yetenek parametrelerinin normal dağılmadığı durumların ve örneklem büyüklüğünün parametre kestirimlerinin keskinliğini nasıl etkileyeceğini açıklayacağından önemlidir. Araştırmanın amacı doğrultusunda çarpıklık katsayıları 2,00, 1,00, 0,00, $-1,00$ ve $-2,00$ olan ve 250, 500, 1,000 ve 2,000 örneklem büyüklüklerinde veriler ve uzunluğu 30 maddeden oluşan bir test için madde parametreleri R programlama dilinde üretilmiştir. Üretilen her bir veri seti için 100 replikasyon gerçekleştirilmiş ve madde parametrelerinin kestirimleri $\mathrm{R}$ programlama dili kullanılarak mirt paketinde marginal maximum xi likelihood (MML) kestirim yöntemi yardımıyla gerçekleştirilmiştir. Parametre kestirim keskinliğini değerlendirmek içinse hata kareleri ortalamasının karekökü (root mean squared error-RMSE) ve Bias istatistikleri kullanılmıştır. Araştırmanın bulgularında çarpıklık katsayıları mutlak değerce büyüdüğünde a parametreleri için RMSE değerlerinin büyüdüğü ve Bias değerlerinin sıfırdan uzaklaştı̆ı, b parametreleri için çarpıklık katsayıları mutlak değerce büyüdüğünde hemen hemen aynı RMSE ve Bias değerlerinin elde edildiği görülmüştür. Örneklem büyüklükleri arttığında a parametreleri için tüm dağıımlarda RMSE değerlerinin küçüldüğü ve Bias değerlerinin hemen hemen aynı değerlerde olduğu, b parametreleri içinse örneklem büyüklüğü arttıkça RMSE değerlerinin küçüldüğü ve Bias değerlerinin çarpıklık katsayısına göre bazen sıfıra yaklaştığı bazen de sıfırdan uzaklaştığı görülmüştür. Normal dağıımdan elde edilen sonuçlar diğer çarpıklık katsayılarına sahip dağıımlardan elde edilen sonuçlar ile karşılaştırıldığında en küçük RMSE ve sıfıra en yakın Bias değerlerini ürettiği görülmüştür.

Anahtar Kelimeler: Madde Tepki Kuramı, Parametre Kestirimi, Monte Carlo Simülasyonu, Çarpık Dağıım.

\section{Abstract}

Tests consisting of dichotomously scored items are frequently used in education and psychology. These tests, which can be used with logistic models under item response theory, have some features that make the estimation more accurate when estimating

\footnotetext{
* Corresponding author:

İbrahim Alper Köse, Department of Educational Sciences, Faculty of Education, Bolu Abant İzzet Baysal University, Bolu, Turkey. Email: i.alper.kose@gmail.com
} 
item parameters but groups in which tests are applied may not always provide these features. The aim of this study is to analyze the effects of various features of the data set on the accuracy of the parameter estimates in the analysis of a data set consisting of dichotomously scored items with a 2 parameter logistic (2 PL) model. This study is important because it will explain how the ability parameters obtained from dichotomously scored tests have not normal distribution and the sample size will affect the accuracy of parameter estimates. For the purpose of the study, item parameters for a test with skewness coefficients 2,00, 1,00, $0,00,-1,00$ and $-2,00$ and with sample sizes of $250,500,1,000$ and 2,000 and a length of 30 items were produced in the $R$ programming language. 100 replications were performed for each data set produced and the estimations of the item parameters were performed with the help of the marginal maximum likelihood (MML) xiii estimation method in the mirt pack using the $R$ programming language. To evaluate parameter estimation accuracy, root mean squared error (RMSE) and Bias statistics were used. The results of the study showed that RMSE values for parameters a increased when the skewness coefficients increased by absolute value and Bias values moved away from zero, and that almost identical RMSE and Bias values were obtained when the skewness coefficients for parameters $b$ increased by absolute value. When the sample sizes increased, it was observed that RMSE values decreases in all distributions for the a parameters and the Bias values were almost the same, for the b parameters, the RMSE values decreases as the sample size increased, and the Bias values sometimes approached to zero compared to the skewness coefficient. When the results obtained from the normal distribution are compared with the results obtained from the distributions with other skewness coefficients, it is seen that it produces the smallest RMSE and the Bias values closest to zero.

Keywords: Item Response Theory, Parameter Estimation, Monte Carlo Simulation, Skewed Distribution.

Received:07 May 2021 * Accepted: 21 June $2021 \quad$ * DOI: https://doi.org/10.29329/dmer.2021.285.1

\section{GİRIŞ}

Psikolojik yapılar örneğin matematik yeteneği gibi doğrudan gözlemlenip ölçülemediğinden bu yapıları dolaylı yoldan ölçebilecek araçlar tasarlanmıştır (Crocker ve Algina, 2008; Lord ve Novick, 2008). Bu araçlardan çoktan seçmeli testler eğitimde birçok özelliği ya da psikolojik yapıyı ölçmek için geliştirilen ve geniş bir kullanım alanı olan ölçme araçlarıdır (Ebel ve Frisbie, 1991). Bu araçlardan içinde doğru cevabın da yer aldığı birden fazla seçenekten seçerek cevaplanan ölçme aracı en sık kullanılandır (Marso ve Piggie, 1988).

Alanyazında çoktan seçmeli maddelerden elde edilen verilerin hem Klasik Test Kuramı (KTK) hem de Madde Tepki Kuramı (MTK)'na göre madde ve test istatistikleri elde edilmektedir (Finch ve French 2019). Son yıllarda ise bu ölçme araçlarından elde edilen veri setlerinin MTK modelleri ile analiz edilmesi gittikçe yaygınlaşmaktadır. Ancak ölçme aracının uygulandığı çalışma grubundan elde edilen sonuçların normal dağılmıyor olması normal ogive MTK modellerinde bulunan normallik varsayımını ihlal etmektedir.

Stone (1992), yapmış olduğu çalışmada 2PL model altında MULTILOG yazılımını değerlendirmeye çalışmıştır. Bu amaç doğrultusunda farklı test uzunluğu (10, 20, 40 madde), örneklem büyüklüğü $(250,500,1000), \theta$ dağılımı (normal dağılım, pozitif çarpık $(C ̧ K=0.75, \mathrm{BK}=0.0)$ ve basıklık 
$(C ̧ K=0, \mathrm{BK}=-1.0)$ değiş̧kenlerini manipüle ederek parametre kestirim keskinliğini incelemiştir. Çalışma incelendiğinde bu araştırmadaki gibi normal dağılımın diğer dağılımlardan daha iyi RMSE değerleri verdiği, a ve b parametrelerinin kestiriminden elde edilen RMSE ve Bias değerlerinin bu çalışmayla hemen hemen paralel yönde değerler ürettiği görülmüştür.

Seong (1990), çalışmasında önsel (prior) $\theta$ dağılımlarının gerçek $\theta$ dağılımlarıyla uyuşmadığında madde ve $\theta$ parametrelerinin kestirimindeki hassasiyeti öğrenmeye çalışmıştır. Bu amaçla 100 ve 1000 örneklem büyüklüklerinde, normal dağılıma sahip bir $\theta$ dağılımının yanında ÇK $=-1.0$ ve 1.0 olan 3 farklı $\theta$ dağılımı kullanarak kırk beşer maddeden oluşan 30 adet veri seti oluşturmuştur. Araştırmacının ulaştığı sonuçlar doğrultusunda bu çalışmayla neredeyse tamamen zit olduğu görülmüştür.

Kieftenbeld ve Natesan (2012), çalışmalarında Dereceli Tepki Modelinde (Graded Response Model (GRM)) $\theta$ parametrelerinin dağılımı, test uzunluğu ve örneklem büyüklüğü değişkenlerini manipüle ederek MML/EAP ve Markov Chain Monte Carlo (MCMC) kestirim yöntemlerinin keskinliğini karşılaştırmayı ve OpenBUGS yazılımının performansını gözlemlemeyi amaçlamışlardır. $\mathrm{Bu}$ doğrultuda $\theta$ parametreleri için 3 farklı dağılım türü (normal, skew-normal $(C ̧ K=1,25, \mathrm{BK}=1,5)$ ve uniform), 5 farklı örneklem büyüklüğü $(75,150,300,500$ ve 1,000) ve 4 farklı test uzunluğu $(5,10,15$, 20) kullanmışlardır. Çalışma incelendiğinde tüm test uzunluklarında örneklem büyüdükçe elde edilen RMSE değerlerinin küçüldüğü bu nedenle bu çalışmayı desteklediği söylenebilir.

Boulet (1996), parametre kestiriminde full-information (FI) ve limited-information (LI) metotlarının kullanıldığı durumlarda $\theta$ parametrelerinin çarpık dağılımının parametre kestirim keskinliğine etkisini incelemek istemiştir. $\mathrm{Bu}$ amaç doğrultusunda 2PL model üzerinde çalışan araştırmacı 15, 30, 45 ve 60 maddelik testlerin yanında 250, 500, 1,000 ve 10,000 örneklem büyüklükleri kullanılmıştır. Araştırma incelendiğinde bazı durumların bu çalışmayı desteklediği görülürken bazılarının desteklemediği ortaya çıkmıştır.

Abdel-fattah (1994), araştırmasında 3PL model üzerinde BILOG ve LOGIST yazılımlarını karşılaştırmayı amaçlamıştır. Bu amaç doğrultusunda 20 ve 60 maddelik test uzunluklarının yanında $\mathrm{N}=250$ ve $\mathrm{N}=1,000$ örneklem büyüklüklerini kullanmıştır. Araştırma incelendiğinde bazı durumların bu çalışmayı desteklediği görülürken bazılarının desteklemediği ortaya çıkmıştır.

$\mathrm{Bu}$ araştırma özellikle normal dağılımı bir varsayım olarak görmeyen lojistik modellerde normallikten hem negatif hem de pozitif yönde saptıkça parametre kestirim keskinliğinin nasıl etkilendiğine, bu etkinin örneklem büyüklüğünden etkilenip etkilenmediğine ve R programlama dilinde nasıl performans göstereceğine cevap olacağı için önemlidir.

\section{Ölçme Keskinliği}

Eğitim ve psikoloji gibi dolaylı ölçüm işlemlerinin yapıldığı bilim dallarında uygulamalı ya da deneysel bilim dallarında olduğu gibi ölçme işlemlerine karışan hataların kestiriminde kesin bir yöntem 
ya da katsayı belirlenemez. Eğitimde ve psikolojide ölçme işlemine karışan hatalar ölçme işleminin çalışma grubuna tekrar tekrar uygulanması ile tespit edilebilir (Turgut ve Baykul, 2015). Ancak ölçme işlemlerinde, pratikte bir ölçme işleminin sonsuz kez uygulanamayacağı gerçeğinden hareketle gerçek durum ya da puan ile gözlenen durum ya da puan arasındaki farkın olabilecek en düşük değerde tutulması esas alınmaktadır. Bu farklara "hata" denilmekle beraber ölçme işleminin kalitesinin yani keskinliğinin yorumlanmasında yardımcı olur.

MTK'de gerek parametre kestirim yöntemlerinin verimliliğini gerekse çeşitli koşullarda madde ve birey parametrelerinin ne derece hassaslıkta kestirildiğini öğrenmek için çeşitli simülasyon çalışmaları yapılmaktadır (Feinberg ve Rubright, 2016). Bu simülasyon çalışmaları ise şu birkaç adımda gerçekleştirilmektedir;

1. Bir MTK modeli seçilir.

2. Modelin madde ile birey parametreleri test uzunluğu, örneklem büyüklüğü gibi farklı koşullar altında üretilir.

3. Modelin parametre değerlerini kestirmek için bir ya da daha fazla sayıda kestirim yöntemi belirlenir ve kestirim işlemi yapılır.

4. Üretilen parametre değerleri ile kestirim sonucu elde edilen parametre değerleri karşılaştırılarak sonuca var1lır (Luecht ve Ackerman, 2018).

Yukarıdaki adımlar incelendiğinde aslında 2. maddenin bir ölçme işlemindeki gerçek durumu ya da puanı 3. maddenin ise gözlenen durumu ya da puanı temsil ettiği ve 4. maddede ise gerçek puan ile gözlenen puan arasındaki farkın incelendiği yani "hata" değerlerine bakıldığı anlaşılabilecektir. 4. maddede yapılacak olan karşılaştırma işlemini yorumlamak için MTK'de "hata kareleri ortalamasının karekökü (root mean squared error (RMSE))” ve “yanlılık (Bias)” değerleri kullanılabilir. Yanlılık değerini bulmak için;

$$
\text { Bias }=\frac{\sum_{i=1}^{K}\left(\hat{X}_{i}-X_{i}\right)}{K}
$$

formülü kullanılabilir. Burada $\mathrm{K}$ toplam madde sayısını, i madde numarasını, $\widehat{X \imath}$ kestirilen i. madde parametre değerini, $\mathrm{X}_{\mathrm{i}}$ ise üretilen yani gerçek madde parametre değerini göstermektedir. RMSE değerini bulmak içinse;

$$
R M S E=\sqrt{\frac{\sum_{i=1}^{K}\left(\hat{X}_{i}-X_{i}\right)^{2}}{K}}
$$

formülü kullanılabilir. Bu formüllerden ne kadar küçük değerler elde edilirse ölçme işleminin ya da parametre geri kazanımının o kadar hatasız olduğunu söylenebilir, işlemin keskinliği yorumlanabilir. 


\section{YÖNTEM}

\section{Araştırmanın Modeli}

$\mathrm{Bu}$ araştırma, farklı örneklem büyüklüklerinin ve farklı yetenek düzeyi ( $\theta$ ) dağılımlarının kullanılarak 2 parametreli lojistik (2PL) model altında üretilen madde parametrelerini gerçek parametre değerleri olarak ele alıp daha sonra yapılan kestirim işlemleri sonunda ortaya çıkan madde parametrelerini RMSE ve Bias istatistikleri yardımıyla karşılaştırarak ölçme keskinliği hakkında fikir sahibi olmak amacıyla gerçekleştirilmiştir.

Bu amaç doğrultusunda izlenen adımlar (Meyers ve Grossen, 1974);

1. Bir durumun belli özelliklerinin manipüle edilmesi.

2. Bu manipüle işleminin kontrollü olarak gerçekleştirilmesi.

3. Manipüle işlemi sonunda elde edilen sonuçlar gözlemlenebilmesi ve hakkında veri toplanabilmesi.

olduğundan yapılan araştırma bir betimleme modelidir.

\section{Simülasyon Faktörleri ve Koşulları}

$\mathrm{Bu}$ araştırmada, çeşitli koşulların parametre kestirimi üzerindeki etkisini belirlemek amacıyla MC simülasyon çalışması yapılmıştır. Hulin vd., 1982; Karadavut, 2017; Stone, 1992; Olmuş vd., 2016; Seong, 1990 araştırmalarında örneklem büyüklügünün ve $\theta$ dağılımının parametre kestirimini etkilediği görülmüş olup bu faktörler simülasyon çalışmasında manipüle edilecek faktörler olarak belirlenmiştir.

Araştırmada manipüle edilen değişkenlerden ilki $\theta$ dağılımlarıdır. $\theta$ dağılımlarının çarpıklık katsayısı daha önceki çalışmalarda kullanılan dağılımlar da göz önünde bulundurularak geniş bir alanı kapsamak için $-2,00,-1,00,1,00,2,00$ ve standart normal dağılım olmak üzere 5 düzey olarak belirlenmiştir (Stone, 1992; Sass vd., 2008; Yıldırım, 2015; Swaminathan ve Gifford, 1979; Reise ve Yu, 1990). Daha sonra her bir durum birbirleriyle karşılaştırılmış böylece 10 farklı durum kontrol edilmiştir.

İkinci faktör olarak ise örneklem büyüklüğü seçilmiştir. Örneklem büyüklüğü daha önce yapılan ölçme keskinliği çalışmalarında belirleyici bir etken olarak öne çıkmıştır ve örneklem büyüklüğü arttıkça ölçme keskinliğinin arttığı görülmüştür. Bu araştırmalardan yola çıkarak 250, 500, 1000 ve 2000 kişilik 4 örneklem büyüklüğü seçilmiştir (Drasgow, 1989; Seong, 1990; Hulin vd., 1982; Lord, 1968; Swaminathan ve Gifford, 1979).

Sabit tutulan faktörlerden biri olan replikasyon sayısı, MC çalışmalarında manipüle edilen değişkenlerin gözlemlenmek istenen durumlar üzerindeki etkisini daha net görebilmek için yüksek sayılarda tutulması gereklidir. Çalışmanın amacına göre değişebilen bu sayı örneklem büyüklügünün ve 
test uzunluğunun yeterli olduğu miktarlarda 100 'den az durumlarda iyi sonuçlar verebilmektedir (Harwell vd., 1996). Elde edilen bulguların 1şığında bu araştırmada 100 replikasyon kullanılması uygun görülmüştür.

Sabit olan bir diğer faktör ise test uzunluğu yani bir veri setinde kullanılan madde sayısıdır. İncelenen çalışmalarda farklı test uzunluklarının kullanıldığ 1 görülmüştür. Genel olarak bir testte bulunan madde sayısı eğitimde ve psikolojide sıkça kullanılan testlerde bulunan 20 ile 40 madde arasında değişmektedir. (Hulin vd., 1982; Lord, 1968; Yen, 1987; Abdel-fattah, 1994; Stone, 1992; Swaminathan ve Gifford, 1979). Test uzunluğunun çalışmayı etkilememesi ve yalnızca manipüle edilen değişkenlerin gözlemlenmek istenen durumlar üzerindeki etkisinin bilinmek istenmesi sebepleriyle bu çalışmada alanyazından elde edilen veriler ışığında bir parametre keskinliği çalışmasında 2PL model altında 30 maddenin kullanılması uygun görülmüştür (Hulin vd., 1982).

Araştırmada 2PL model kullanılmıştır. Bu modelin seçilme amacı diğer modellerden daha tutarlı kestirimler vermesi ve bununla birlikte gerçek durumlara olabildiğince yakın olmasıdır (de Ayala, 2009).

Sonuç olarak 5 adet $\theta$ dağılımı ve 4 adet örneklem büyüklüğünün kullanıldığı bu çalışmada toplam 5x4=20 koşul incelenmiştir. Araştırma 100 replikasyon sayısıyla gerçekleştirilmiştir. Yani bu 20 koşulun her biri $100 \mathrm{kez}$ tekrarlanmıştır ve bu işlemlerin sonucunda toplam 20x100=2000 veri seti elde edilmiştir. Tablo 1'de simülasyon koşulları gösterilmiştir..

Tablo 1. Araştırmaya dair manipüle edilen simülasyon koşulları

\begin{tabular}{|c|c|}
\hline Örneklem Büyüklüğü (N) & Yetenek ( $\theta$ ) Dağılımı (ÇK) \\
\hline \multirow{5}{*}{$\mathrm{N}=250$} & -2.00 \\
\hline & -1.00 \\
\hline & 0.00 \\
\hline & 1.00 \\
\hline & 2.00 \\
\hline \multirow{5}{*}{$\mathrm{N}=500$} & -2.00 \\
\hline & -1.00 \\
\hline & 0.00 \\
\hline & 1.00 \\
\hline & 2.00 \\
\hline \multirow{5}{*}{$\mathrm{N}=1000$} & -2.00 \\
\hline & -1.00 \\
\hline & 0.00 \\
\hline & 1.00 \\
\hline & 2.00 \\
\hline
\end{tabular}




\section{Verilerin Üretilmesi}

$\mathrm{Bu}$ çalışmada veri setleri 2PL model altında yapay olarak üretilmiştir. Araştırmanın verilerini üretmek için alt problemlere uygun olarak madde ve birey parametreleri oluşturulmuştur. Bu amaç doğrultusunda 2PL modele uygun olarak kullanılan madde sayısı kadar a ve b parametre değerleri, değişen örneklem büyüklüğüne bağlı olarak da $\theta$ parametre değerleri üretilmiştir.

$\mathrm{Bu}$ çalışmada kullanılan Monte Carlo (MC) simülasyon çalışmasının şartlarını yerine getirmek amacıyla madde parametreleri üretilirken gerçek durumların yansıtılmasına dikkat edilmiştir. $\mathrm{Bu}$ nedenle a parametresi ortalamas1 0 standart sapmas1 0.5 olan rastgele log-normal, b parametresi ise rastgele standart normal dağılımdan üretilmiştir (Abdel-fattah, 1994; Eser ve Gelbal, 2015; Uysal vd., 2019; Sünbül ve Bulut, 2017; Feinberg ve Rubright, 2016).

Çalışmada ilk olarak madde parametreleri üretilmiştir. Bu parametreler üretilirken daha önce yapılan çalışmalar incelenmiş ve gerçek durumlara uygun olabilecek dağılımlar kullanılarak üretim işlemi gerçekleştirilmiştir. Bu amaç doğrultusunda a parametresi log-normal dağıllımdan rastgele $\mathrm{a} \sim \ln \mathrm{N}(0,0,0,5)$, b parametresi standart normal dağ 1 lımdan rastgele $\mathrm{b} \sim \mathrm{N}(0,0,1,0)$ üretilmiştir (Seong, 1990; Feinberg ve Rubright, 2016; Bulut ve Sünbül, 2017). Madde parametrelerini üretmek için RStudio yazılımında R programlama dili kullanılmıştır.

Nihayetinde madde parametrelerinin üretimi için kullanılan parametreler Tablo 2'de görülebilir.

Tablo 2. Madde parametrelerini (a, b) üretmek için kullanılan parametre değerleri

\begin{tabular}{lcc}
\hline Madde Parametreleri & \multicolumn{2}{c}{ Kullanılan Parametre Değerleri } \\
\hline & Ortalama & Standart Sapma \\
\cline { 2 - 3 } Madde Ayırt Edicilik (a) & 0 & 0.5 \\
\hline & Ortalama & Standart Sapma \\
\cline { 2 - 3 } Madde Güçlük (b) & 0 & 1 \\
\hline
\end{tabular}

Araştırmada daha sonra $\theta$ parametreleri üretilmiştir. $\mathrm{Bu}$ parametreler de üretilirken daha önce yapılmış olan çalışmalar incelenmiş ve gerçek durumlara en uygun olabilecek dağılımlar seçilmeye çalışılmıştır. Bu amaç doğrultusunda $\theta$ parametreleri beta dağılımından rastgele üretilmiştir. İstenilen çarpıklık değerlerinde veri üretmek için negatif çarpıklık katsayısından $(-2,0,-1,0)$ pozitif çarpıklık katsayısına $(1,0,2,0)$ doğru sirasıyla $\theta \sim \operatorname{BETA}(21,0,0,8 ; 9,0,1,45 ; 1,45,9,0 ; 0,8,21,0)$ katsayıları kullanılmıştır. Ardından istenilen $\theta$ değerlerine ulaşmak amacıyla üretilen her bir değerden ÇK= $-2,00$ durumunda 0,965 çıarılmış ve elde edilen sonuç 25,7 ile çarpılmıştır bu işlem diğer çarpıklık katsayılarının üretildiği durumlarda ÇK= $-1,00$ için 0,86 değerinin çıkarılıp 10,7 ile çarpılarak, ÇK= 1,00 için 0,14 değeri çıkarılıp 10,7 ile çarpılarak, ÇK=2,00 için 0,035 çıkarılıp 25,7 ile çarpılarak devam etmiştir (DeMars, 2003; Abdel-fattah, 1994; Swaminathan ve Gifford, 1979). Bu işlemlerin ardından 
elde edilen dağılımların yazılan kodlarla standart sapmalarının 1'e, ortalamalarının 0'a sabit olduğundan ve istenilen çarpıklık katsayılarına sahip olduğundan emin olunmuştur. Standart normal dağılıma $N(0,1)$ sahip yetenek $(\theta)$ parametreleri de dahil olmak üzere $\theta$ parametreleri RStudio yazılımında $R$ programlama dili kullanılarak üretilmiştir.

Sonuç olarak kullanılan çarpık dağılımlar, bu dağılımları üretmek için kullanılan katsayılar ve istenilen özelliklere sahip olması için gerekli olan çıkarma ve çarpma işlemlerinde kullanılan değerler Tablo 3'te görülebilir.

Tablo 3. Çarpıklık düzeylerine göre kullanılan parametre değerleri

\begin{tabular}{|c|c|c|c|c|}
\hline \multirow[t]{2}{*}{ Çarpıklık Düzeyi } & \multicolumn{2}{|c|}{$\begin{array}{c}\text { Kullanılan Parametre } \\
\text { Değerleri }\end{array}$} & \multirow{2}{*}{$\begin{array}{c}\text { Üretilen her bir } \\
\text { sayıdan çlkarılan } \\
\text { değer }\end{array}$} & \multirow{2}{*}{$\begin{array}{c}\text { Çıkarma işleminden } \\
\text { sonra elde edilen her bir } \\
\text { sayının çarpıldığı değer }\end{array}$} \\
\hline & Ortalama & $\begin{array}{l}\text { Standart } \\
\text { Sapma }\end{array}$ & & \\
\hline \multirow[t]{2}{*}{$\mathrm{ÇK}=0,00$} & 0 & 1 & & \\
\hline & $\alpha$ & $\beta$ & & \\
\hline $\mathrm{C} K=2,00$ & 0,8 & 21 & 0,035 & 25,7 \\
\hline $\mathrm{C} K=1,00$ & 1,45 & 9 & 0,14 & 10,7 \\
\hline $\mathrm{C} K=-1,00$ & 9 & 1,45 & 0,86 & 10,7 \\
\hline $\mathrm{CK}=-2,00$ & 21 & 0,8 & 0,965 & 25,7 \\
\hline
\end{tabular}

\section{Verilerin Analizi}

Araştırmaya dair tüm işlemler RStudio v1.2.1335 programında R v3.6.1 yazılımı kullanılarak gerçekleştirilmiştir. Madde ve yetenek $(\theta)$ parametrelerinin üretimi $\mathrm{R}$ yazılımına ait çekirdek paket programlarla gerçekleştirilmiştir. Madde parametrelerinin tahmini için "mirt" paketi kullanılmıştır. Bu paket açımlayıcı ve doğrulayıcı modeller için çok boyutlu madde tepki kuramının parametrelerini maximum likelihood yöntemleri ile tahmin etmesi amaciyla oluşturulmuştur (Chalmers, 2012). Bu amacının yanında tek boyutlu lojistik modeller için de tahmin işlemleri gerçekleştirilebilir. "mirt" paketi varsayılan biçimde Marginal Maximum Likelihood (MML) kestirim yöntemini kullanmaktadır (Paek ve Cole, 2019). Ayrıca kestirim işleminde çeşitli durumlara göre kullanılmak üzere Metropolis-Hastings Robbins-Monro (MH-RM) ve Expectaion-Maximization (EM) algoritmaları da bulunmaktadır. Bu çalışma için MML kestirim yöntemi ve EM algoritması kullanılmıştır.

Veri üretiminden analizine geçişteki ilk adımda üretilen parametreler doğrultusunda her bir birey için 0 ve 1'lerden oluşan bir cevap matrisi oluşturmaktadır. Daha sonra oluşan cevap matrisleri kullanılarak parametre tahmini gerçekleştirilmiştir. Yapılan kestirim işlemi sonucunda parametre değerleri elde edilmiş ve bir fonksiyona toplanmıştır. Sonuç olarak fonksiyonlardan gerçek parametre 
değerleri ile kestirilen parametre değerleri arasındaki farklar Bias ve RMSE istatistikleri yardımıyla değerlendirilmiştir.

\section{BULGULAR ve YORUMLAR}

Lord (1968) ve Drasgow (1989)'un önerileri doğrultusunda örneklem büyüklüğünün N=1,000’e sabitlendiği ve $\theta$ parametrelerinin dağılım durumlarının parametre kestirimlerine etkisinin incelendiği çalışma deseninden elde edilen sonuçlar Tablo 4 ve Tablo 5 'te incelenebilir.

Tablo 4. Farklı Dağılımlar İçin a Parametresinin Ortalama RMSE ve Bias Değerleri

\begin{tabular}{ccccc}
\hline $\begin{array}{c}\text { Örneklem } \\
\text { Büyüklü̆ğü (N) }\end{array}$ & Test Uzunluğu & $\begin{array}{c}\text { Çarpıklık } \\
\text { Katsayısı (ÇK) }\end{array}$ & Ortalama RMSE & Ortalama Bias \\
\hline \multirow{3}{*}{$\mathrm{N}=1000$} & 30 & ÇK=2,00 & 0,243 & 0,140 \\
& 30 & ÇK $=-2,00$ & 0,254 & $-0,147$ \\
& 30 & ÇK $=1,00$ & 0,154 & 0,030 \\
& 30 & ÇK $=-1,00$ & 0,147 & 0,028 \\
& 30 & $C ̧ K=0,00$ & 0,121 & 0,005 \\
\hline
\end{tabular}

Tablo 5. Farklı dağılımlar için b parametrelerinin ortalama RMSE ve Bias değerleri

\begin{tabular}{ccccc}
\hline $\begin{array}{c}\text { Örneklem } \\
\text { Büyüiklüğü (N) }\end{array}$ & Test Uzunluğu & $\begin{array}{c}\text { Çarpıklık } \\
\text { Katsayısı (ÇK) }\end{array}$ & Ortalama RMSE & Ortalama Bias \\
\hline \multirow{3}{*}{$\mathrm{N}=1000$} & 30 & ÇK=2,00 & 0,136 & $-0,066$ \\
& 30 & ÇK $=-2,00$ & 0,143 & 0,071 \\
& 30 & ÇK=1,00 & 0,153 & $-0,091$ \\
& 30 & ÇK $=-1,00$ & 0,151 & 0,094 \\
& 30 & ÇK=0,00 & 0,093 & $-0,001$ \\
\hline
\end{tabular}

Tablo 4 incelendiğinde en düşük RMSE ve Bias değeri $(0,121,0,005)$ ÇK= 0,00 yani $\theta$ dağılımı standart normal dağılımken en yüksek RMSE ve Bias değeri $(0,254,-0,147)$ ÇK $=-2,00$ olan dağılımdan elde edilmiştir. Bu sonuçlara bakarak kestirim keskinliği için a parametresinden elde edilen ortalama RMSE değerlerinin oldukça yüksek olduğu söylenebilir. Bunlara ek olarak çarpıklık katsayısının (ÇK) negatif ya da pozitif olması yani dağılımın çarpıklık yönünün RMSE değerleri arasında önemli bir fark yaratmadığı da gözlemlenebilir. Ayrıca a parametresi için $\theta$ parametre dağılımlarının ÇK'si arttıkça RMSE değerlerinin de artma eğiliminde olduğu görülebilir. Bias değerleri 0'a ne kadar yakınlarsa o kadar iyi sonuç alındığına işaret eder böylece en iyi sonucun standart normal dağılımdan alındığı ve dağılımın ÇK'si büyüdükçe değerlerinde kötüleştiği söylenebilir. Bu bilgilere ek olarak ÇK'nin pozitif ya da negatif olması ortalama Bias değerlerini önemli derecede etkilemediği söylenebilir. Ayrıca $\theta$ parametrelerinin ÇK'sinin arttıkça $b$ parametrelerine ait ortalama Bias değerlerinin de artma eğiliminde olduğu görülebilir. 
Tablo 5 incelendiğinde en düşük RMSE ve Bias değerinin $(0,093,-0,001) \theta$ parametreleri standart normal dağılıma sahipken en yüksek RMSE değerinin $(0,153) \theta$ parametreleri ÇK=1,00 olan dağılıma ait olduğu ve mutlak değeri en büyük Bias değerinin $(0,094) \theta$ parametreleri ÇK= $-1,00$ olan dağılımdan elde edildiği görülebilir. Bu sonuçlara bakarak kestirim keskinliği için b parametresinden elde edilen ortalama RMSE değerlerinin yalnızca $\theta$ parametreleri standart normal dağılıma sahipken kabul edilebilir düzeyde olduğu, diğer dağılım türlerinde RMSE değerlerinin oldukça yüksek olduğu söylenebilir. Bunlara ek olarak ÇK'nin pozitif ya da negatif olmasının ortalama RMSE değerleri arasında önemli bir fark yaratmadığı da söylenebilir. Ayrıca ilginç bir şekilde $\theta$ parametrelerinin dağılımı ÇK=1,00 ve ÇK= -1,00 iken çok yüksek değerler almaktayken dağılımların ÇK'si arttıkça bu değerlerde azalma görülmektedir. Bias sonuçları değerlendirilecek olunursa ÇK'nin pozitif ya da negatif yönde olmasının ortalama Bias değerleri üzerinde önemli bir etkiye sahip olmadığı söylenebilir. Ayrıca b parametrelerinin ortalama RMSE değerlerinde görüldüğü üzere Bias parametrelerinde de aynı ilginç durum söz konusudur. Beklenenin aksine ÇK'nin hem pozitif hem de negatif 1 olduğu durumlardan elde edilen ortalama Bias değerleri ÇK'nin hem pozitif hem de negatif 2 olduğu durumlardan büyüktür.

Örneklem büyüklüklerinin $(250,500,1000,2000)$ ve $\theta$ parametrelerinin çeşitli dağglım özelliklerine sahip olduğu durumların (çarpıklık katsayısı $(C ̧ K)=-2,00,-1,00,0,00,1,00,2,00$ ) parametre kestirimlerini nasıl etkilediğine dair elde edilen sonuçlar Tablo 6 ve Tablo 7'de incelenebilir.

Tablo 6. Farklı dağılımlar ve örneklem büyüklükleri için a parametrelerinin ortalama RMSE ve Bias değerleri

\begin{tabular}{cccc}
\hline Çarpıklık Katsayısı (ÇK) & Örneklem Büyüklüğü (N) & Ortalama RMSE & Ortalama Bias \\
\hline ÇK=2,00 & $\mathrm{N}=250$ & 0,310 & $-0,126$ \\
& $\mathrm{~N}=500$ & 0,265 & $-0,138$ \\
$\mathrm{~N}=1000$ & 0,243 & 0,140 \\
& $\mathrm{~N}=2000$ & 0,230 & $-0,140$ \\
\hline $\mathrm{N}=-2,00$ & $\mathrm{~N}=250$ & 0,306 & $-0,128$ \\
& $\mathrm{~N}=500$ & 0,264 & $-0,141$ \\
& $\mathrm{~N}=1000$ & 0,254 & $-0,147$ \\
& $\mathrm{~N}=2000$ & 0,231 & $-0,143$ \\
\hline $\mathrm{C} \mathrm{N}=1,00$ & $\mathrm{~N}=250$ & 0,254 & 0,021 \\
& $\mathrm{~N}=500$ & 0,189 & 0,019 \\
& $\mathrm{~N}=1000$ & 0,154 & 0,030 \\
& $\mathrm{~N}=2000$ & 0,117 & 0,025 \\
\hline $\mathrm{C} K=-1,00$ & $\mathrm{~N}=250$ & 0,262 & 0,024 \\
& $\mathrm{~N}=500$ & 0,191 & 0,019 \\
& $\mathrm{~N}=1000$ & 0,147 & 0,028 \\
& $\mathrm{~N}=2000$ & 0,122 & 0,024 \\
\hline $\mathrm{C} \mathrm{N}=0,00$ & $\mathrm{~N}=250$ & 0,254 & 0,036 \\
& $\mathrm{~N}=500$ & 0,175 & 0,006 \\
\hline
\end{tabular}




\begin{tabular}{ccc}
\hline $\mathrm{N}=1000$ & 0,121 & 0,005 \\
$\mathrm{~N}=2000$ & 0,088 & 0,003 \\
\hline
\end{tabular}

Not: Tüm çalışma desenlerinde test uzunluğu 30 maddeden oluşmaktadır.

Tablo 7. Farklı dağılımlar ve örneklem büyüklükleri için b parametrelerinin ortalama RMSE ve Bias değerleri

\begin{tabular}{|c|c|c|c|}
\hline Çarpıklık Katsayısı (ÇK) & Örneklem Büyüklüğü (N) & Ortalama RMSE & Ortalama Bias \\
\hline \multirow[t]{4}{*}{$\mathrm{ÇK}=2,00$} & $\mathrm{~N}=250$ & 0,221 & $-0,088$ \\
\hline & $\mathrm{N}=500$ & 0,167 & $-0,081$ \\
\hline & $\mathrm{N}=1000$ & 0,136 & $-0,066$ \\
\hline & $\mathrm{N}=2000$ & 0,120 & $-0,064$ \\
\hline \multirow[t]{4}{*}{$C ̧ \mathrm{~K}=-2,00$} & $\mathrm{~N}=250$ & 0,214 & 0,085 \\
\hline & $\mathrm{N}=500$ & 0,168 & 0,077 \\
\hline & $\mathrm{N}=1000$ & 0,143 & 0,071 \\
\hline & $\mathrm{N}=2000$ & 0,119 & 0,064 \\
\hline \multirow[t]{4}{*}{$\mathrm{C} K=1,00$} & $\mathrm{~N}=250$ & 0,200 & $-0,071$ \\
\hline & $\mathrm{N}=500$ & 0,174 & $-0,091$ \\
\hline & $\mathrm{N}=1000$ & 0,153 & $-0,091$ \\
\hline & $\mathrm{N}=2000$ & 0,137 & $-0,095$ \\
\hline \multirow[t]{4}{*}{$\mathrm{C} K=-1,00$} & $\mathrm{~N}=250$ & 0,205 & 0,077 \\
\hline & $\mathrm{N}=500$ & 0,170 & 0,089 \\
\hline & $\mathrm{N}=1000$ & 0,151 & 0,094 \\
\hline & $\mathrm{N}=2000$ & 0,143 & 0,099 \\
\hline \multirow[t]{4}{*}{$\mathrm{CCK}=0,00$} & $\mathrm{~N}=250$ & 0,195 & 0,007 \\
\hline & $\mathrm{N}=500$ & 0,131 & $-0,0001$ \\
\hline & $\mathrm{N}=1000$ & 0,093 & $-0,001$ \\
\hline & $\mathrm{N}=2000$ & 0,065 & $-0,00002$ \\
\hline
\end{tabular}

Not: Tüm çalışma desenlerinde test uzunluğu 30 maddeden oluşmaktadır.

Tablo 6 incelendiğinde bütün dağılım türlerinde örneklem büyüklüğü arttıkça RMSE değerlerinin küçüldüğü, ÇK küçüldükçe RMSE değerlerinin de küçülme eğilimi gösterdiği, ÇK'si mutlak değerde aynı olan dağılımların pozitif ya da negatif olmasının RMSE değerlerinde önemli bir etkiye sahip olmadığı, en iyi sonuçların standart normal dağılıma sahip olan $\theta$ parametrelerinde $\mathrm{N}=2000$ örneklem büyüklüğ̈̈nde $(0,088)$ elde edildiği, en kötü sonuçların $C ̧ K=2,00$ olan $\theta$ parametrelerinde $\mathrm{N}=250$ örneklem büyüklüğü kullanılması halinde $(0,310)$ elde edildiği görülebilir. Ayrıca ÇK'nin hem pozitif hem de negatif 2,00'den hem pozitif hem de negatif 1,00'e düşmesi durumunda RMSE değerlerinde hatırı sayılır küçülme meydana geldiği ancak aynı etkinin ÇK'nin hem pozitif hem de negatif 1'den standart normal dağılıma düşmesi durumunda gözlemlenemediği görülebilir. Aynı tablo incelendiğinde a parametreleri için ortalama Bias değerlerinin tüm dağılım türlerinde örneklem büyüklüğü artışından anlamlı bir etkilenme gerçekleşmediği gözlemlenmiştir. ÇK'nin mutlak değerleri eşit olduğunda ÇK'nin 
pozitif ya da negatif olmasının ortalama Bias değerlerine büyük bir etkisinin olmadığı da gözlemlenebilir. En iyi ortalama Bias değerlerinin $(0,003) \theta$ parametrelerinin standart normal dağılıma sahip olduğu ve $\mathrm{N}=2000$ örneklem büyüklüğünde elde edildiği, en kötü ortalama Bias değerlerininse ($0,147)$ ÇK $=-2,00$ olan dağılımda $\mathrm{N}=1000$ örneklem büyüklüğünde elde edildiği görülebilir. Ayrıca a parametreleri için ortalama Bias değerlerinin $\theta$ parametrelerinin çarpıklık durumuna daha hassas oldukları ve ÇK standart normal dağılıma yaklaştıkça elde edilen ortalama Bias değerlerinin küçüldüğü görülebilir.

Tablo 7 incelendiğinde bütün dağılım türlerinde örneklem büyüklügü arttıkça $\mathrm{b}$ parametrelerine ait ortalama RMSE değerlerinin küçüldüğü görülmüştür. Son derece ilginç bir şekilde örneklem büyüklügünün $\mathrm{N}=250$ olduğu durum dışında $\mathrm{ÇK}=-1,00, \quad$ ÇK $=1,00$ ile ÇK $=-2,00, C ̧ K=2,00$ karşılaştırıldığında beklenilenin aksine örneklem büyüdükçe ÇK= $-1,00$ ile ÇK=1,00, ÇK= $-2,00$ ile ÇK= 2,00'ye göre daha büyük RMSE değerleri verdiği bulgusu elde edilmiştir. b parametrelerinin en iyi ortalama RMSE değerlerinin $(0,065) \theta$ parametrelerinin standart normal dağılıma sahip olduğu ve $\mathrm{N}=2000$ örneklem büyüklügünün kullanıldığı durumda elde edildiği, en kötü ortalama RMSE değerlerininse $(0,221) \theta$ parametrelerinin $C ̧ K=2,00$ olan dağılımdan elde edildiği ve $\mathrm{N}=250$ örneklem büyüklüğ̈̈nün kullanıldığı durumda ortaya çıktığı görülebilir. Bu bilgilere ek olarak mutlak değerleri eşit olan çarpıklık katsayılarının pozitif ya da negatif olmalarının RMSE değerleri üzerinde önemli bir etkilerinin olmadığ 1 da görülebilir. Ayrıca b parametreleri için ÇK'nin hem pozitif hem de negatif 2 değerinin hem pozitif hem de negatif 1 değerine düştüğü durumlarda ortalama RMSE değerlerinde ciddi bir etkinin olmadığı ancak örneklem büyüklüğü arttıkça bu etkinin de ciddi oranlarda arttığı bu durumun özellikle ÇK'nin hem pozitif hem de negatif 1 durumu ile standart normal dağılım durumu karşılaştırıldığında çok daha net şekilde gözlemlenebilir. Aynı tablo incelendiğinde örneklem büyüklüğündeki artışın $C ̧ K=2,00, C ̧ K=-2,00$ ve standart normal dağılıma sahip durumlarda $b$ parametrelerinin ortalama Bias değerlerini genelde 0'a yaklaştırdığı görülmüştür. ÇK=1,00 ve ÇK= 1,00 olan dağılımlarda ise örneklem büyüklüğünde yaşanan artış ortamalama Bias değerlerini 0'dan uzaklaştırmıştır. Mutlak değerleri eşit olan ÇK'lerin pozitif ya da negatif olmasının ortalama Bias değerlerine etkisinin sınırlı olduğu gözlemlenebilir. b parametrelerinin en iyi ortalama Bias değerlerinin $(-0,00002) \theta$ parametrelerinin standart normal dağılıma sahip olduğu ve $\mathrm{N}=2000$ örneklem büyüklüğünde elde edildiği, en kötü ortalama Bias değerlerinin ise $C ̧ K=-1,00$ olan dağılımda ve N=2000 olan örneklem büyüklüğünden $(0,099)$ elde edildiği görülebilir. Ayrıca en kötü sonuçların ÇK'nin negatif değerlerinde elde edildiği de gözlemlenebilir.

\section{SONUÇLAR ve TARTIŞMA}

Örneklem büyüklügünün sabit tutulup yalnızca ÇK'nin değişim gösterdiği durumlarda a parametrelerinin ortalama RMSE değerlerinin olması gerekenden büyük olduğu görülmüştür (Browne ve Cudeck, 1993). Buna rağmen $\theta$ dağılımlarının ÇK'si standart normal dağılıma yaklaştıkça RMSE 
değerlerinde de küçülme görülmüştür. Ortalama RMSE değerlerinin bu kadar yüksek olmasının test uzunluğunun veya örneklem büyüklüğünün yetersiz olmasından kaynaklandığı düşünülmektedir.

Örneklem büyüklüğünün sabit tutulduğu ve yalnızca ÇK'nin değişim gösterdiği durumlarda a parametrelerinin ortalama Bias değerlerinin ÇK standart normal dağılıma yaklaştıkça sıfıra yaklaştığı görülmüştür. Ayrıca ortalama Bias değerlerinin ÇK'nin hem pozitif hem de negatif 2,00 değeri dışında kabul edilebilir düzeylerde olduğu tespit edilmiştir. Elde edilen sonuçlar beklendiği gibidir.

Örneklem büyüklüğünün sabit olduğu ve yalnızca ÇK'nin değişim gösterdiği durumlarda b parametrelerinin ortalama RMSE değerlerinin $C ̧ K=-1,00$ ve $C ̧ K=1,00$ olduğu durumlarda ilginç bir şekilde en büyük değerleri ürettiği görülmüştür. Elde edilen bulgular 1şığında ÇK'nin mutlak değerce en büyük olduğu dağılım için en yüksek RMSE değerinin elde edilememesi durumunun $\mathrm{a}, \mathrm{b}$ ve $\theta$ parametrelerinin dağılımlarının birbirleriyle olan etkileşiminden kaynaklandığı düşünülmektedir.

Örneklem büyüklüğünün sabit olduğu ve yalnızca ÇK'nin değişim gösterdiği durumlarda $b$ parametrelerinin ortalama Bias değerlerinin ortalama RMSE değerlerinden elde edilen sonuçlarla benzerlik taşıdığı görülmüştür. Yine bu durumun yukarıda açıklanan sebepten kaynaklandığı düşünülmektedir.

Elde edilen tüm bu bulguların 1şığında RMSE ve Bias değerlerindeki artış yönü b parametreleri için anormaldir. Ortalama RMSE değerleri için ÇK'nin sırasıyla $-1,00$ ve 1,00 olduğu durumlarda en büyük değeri 0,153 ve ÇK'nin sırasıyla $-2,00$ ve 2,00 olduğu durumlarda en küçük değeri ise 0,136 ' dır. Buradan yola çıkıldığında bu beklenmeyen durumun maksimum farkı 0,017'dir. Yani aslında bu durum oldukça küçük bir farkı işaret etmektedir ve dikkate alınmayabilir. Benzer bir durum ortalama Bias değerleri için de geçerlidir.

Hem örneklem büyüklüğünün hem de ÇK'nin serbest bırakıldığı durumlarda a parametrelerinin ortalama RMSE değerlerinin tüm dağılım türlerinde örneklem büyüklüğü arttıkça düştüğü gözlemlenmiştir. Aynı zamanda $\theta$ parametrelerinin dağılımı standart normal dağılıma yaklaştıkça elde edilen ortalama RMSE değerlerinde küçülme görülmüştür. Elde edilen bulgular 1şığında sonuçlar beklendiği gibidir. Çarpıklık katsayıları ve örneklem büyüklükleri birlikte değerlendirildiğinde a parametreleri için yalnızca $\theta$ parametreleri standart normal dağılıma sahipken ve $N=2,000$ örneklem büyüklünde kabul edilebilir sonuçlar elde edilmiştir.

Hem örneklem büyüklüğünün hem de ÇK'nin serbest olduğu durumlarda a parametrelerinin ortalama Bias değerlerinin dağılımların çarpıklığından oldukça ciddi biçimde etkilendiği gözlemlenmiştir. Beklendiği üzere $\theta$ parametrelerinin dağılımı standart normal dağılıma yaklaştıkça ortalama Bias değerleri de sıfıra yaklaşmaktadır. Ancak dağılımlar kendi içlerinde değerlendirildiğinde örneklem büyüklüğü arttıkça ortalama Bias değerlerinin de sıfira yaklaştığı tek dağılımın standart normal dağılım olduğu, diğer dağılımların genelde örneklem büyüklüğü arttıkça ortalama Bias 
değerlerinin de sıfırdan uzaklaşma eğiliminde olduğu görülebilir. Bu oldukça ilginç bir bulgudur ve bu duruma $\mathrm{a}, \mathrm{b}$ ve $\theta$ parametrelerinin dağılımlarının birbirleriyle olan etkileşimlerinin veya madde sayısının yetersiz kalmasının sebep olduğu düşünülmektedir. Ancak yine elde edilen bulgulardan yola çıkarak bu uzaklaşmanın maksimum olduğu noktada farkın 0,019 olduğu görülmüştür. Yani aslında standart normal dağılım haricinde kalan dağılımların kendi içlerinde yakın Bias değerleri ürettiği söylenebilir. Tüm bu bilgiler değerlendirildiğinde $C ̧ K=-2,00$ ve $C ̧ K=2,00$ dağılımları dışında tüm örneklem büyüklükleri için Bias değerlerinin sıfıra oldukça yakın değerler ürettiği söylenebilir.

Hem örneklem büyüklügünün hem de ÇK'nin manipüle edildiği durumlarda beklenildiği gibi b parametrelerinin ortalama RMSE değerlerinin tüm dağılım türlerinde örneklem büyüklüğü arttıkça azalma eğiliminde olduğu görülmüştür. Ancak ilginç bir şekilde ÇK=-2,00 ve $C ̧ K=2,00$ olan dağılımların $C ̧ K=-1,00$ ve $C ̧ K=1,00$ olan dağılımlarından $\mathrm{N}=250$ örneklem büyüklüğü dışındaki tüm örneklem büyüklüklerinde daha küçük ortalama RMSE değerleri üretmiştir. Ancak normal dağılmayan dağılımlar arasından elde edilen bu ortalama RMSE değerlerine bakıldığında en büyük farkın 0,024 olduğu görülmektedir. Bu nedenle aslında çarpık dağılımların birbirlerine yakın değerler ürettiği söylenebilir. . Elde edilen sonuçların 1şığında RMSE değerlerinde görülen küçülme beklendiği gibidir ancak yalnızca standart normal dağılımda $\mathrm{N}=1,000$ ve $\mathrm{N}=2,000$ örneklem büyüklüklerinde kabul edilebilir RMSE değerleri (sırasıyla 0,093 ve 0,065) elde edilmiştir.

Hem örneklem büyüklüğünün hem de ÇK'nin serbest olduğu durumlarda b parametrelerinin ortalama Bias değerleri ÇK=1,00 ve ÇK=-1,00 olan dağılımlar hariç örneklem büyüklüğü arttıkça sıfira yaklaşma eğiliminde olmuşlardır. ÇK=-1,00 ve ÇK=1,00 olan dağılımlarda ise örneklem büyüklüğü arttıkça ortalama Bias değerleri sıfırdan uzaklaşma eğilimindedirler. ÇK=-1,00 ve ÇK=1,00 dişında sonuçlar beklenildiği gibidir. ÇK=-1,00 ve ÇK=1,00 olan dağılımlarda gözlenen bu ilginç sonuçlara a, $\mathrm{b}$ ve $\theta$ parametrelerinin dağılımlarının birbirleriyle olan ilişkisinin neden olduğu düşünülmektedir. Ancak tüm örneklem büyüklüklerinde bu dağılımlardan elde edilen sonuçlar incelendiğinde ÇK=-1,00 için ortalama Bias değerlerinin maksimum farkının 0,022, ÇK=1,00 için ortalama Bias değerlerinin maksimum farkının 0,024 olduğu görülmektedir. Bu farklar doğrultusunda aslında ÇK=-1,00 ve ÇK=1,00 dağılımlarından elde edilen ortalama Bias değerlerinin birbirlerine çok yakın olduğu ve elde edilen sonucun 1şığında bu artışın göz ardı edilebileceği söylenebilir. Ayrıca tüm dağılım türleri ve örneklem büyüklükleri için elde edilen ortalama Bias değerleri kabul edilebilir sınırlar dâhilindedir. Tüm bu bilgiler değerlendirildiğinde b parametrelerinin ortalama Bias değerlerinin çarpıklık katsayılarına ya da örneklem büyüklüğüne bakılmaksızın sıfıra oldukça yakın ve kabul edilebilir eşiklerde olduğu söylenebilir.

Madde ayırt edicilik (a) parametreleri için örneklem büyüklüğü sabit tutulup $(\mathrm{N}=1,000)$ yalnızca ÇK manipüle edildiğinde ortalama RMSE değerleri ÇK standart normal dağılıma yaklaştıkça küçülmektedir. Bu sonuç 2 parametreli normal ogive model altında 45 maddelik bir test ve $N=1,000$ 
örneklem büyüklüğünü kullanan Seong (1990)'un çalışmasıyla uyuşmamaktadır. Stone (1992)'un çalışması incelendiğinde $2 \mathrm{PL}$ model altında test uzunluğunu, örneklem büyüklügünü ve $\theta$ parametrelerinin dağılımını manipüle eden araştırmacının elde ettiği bulgular bu çalışmayı desteklemektedir. Kieftenbeld ve Natesan (2012)'ın çalışmaları incelendiğinde Derecelendirilmiş Tepki Modeli (Graded Response Model) üzerinde $\theta$ dağılımlarını, örneklem büyüklüğünü ve test uzunluğunu manipüle eden araştırmacıların elde ettiği bulguların bazıları bu çalışmayı desteklerken bazıları da desteklememektedir. Boulet (1996)'in çalışması incelendiğinde 2 PL model altında test uzunluğunu, örneklem büyüklüğünü ve $\theta$ dağılımlarını manipüle eden araştırmacının a parametresi için RMSE istatistiğinden elde ettiği sonuçlar tüm test uzunlukları, örneklem büyüklükleri ve kullanılan yazılımlar için bu araştırmayı tamamen desteklemektedir. Sass vd. (2008)'nin çalışmaları incelendiğinde 2 PL model altında $b$ parametrelerinin ve $\theta$ parametrelerinin dağılımını manipüle eden araştırmacıların RMSE istatistiğinden elde ettikleri sonuçlar bu çalışmayı desteklemektedir.

Madde ayırt edicilik (a) parametreleri için örneklem büyüklüğü sabit tutulup $(\mathrm{N}=1,000)$ yalnızca ÇK manipüle edildiğinde ortalama Bias değerleri ÇK standart normal dağılıma yaklaştıkça küçülmektedir. Bu sonuç 2 parametreli normal ogive model altında 45 maddelik bir test ve $\mathrm{N}=1,000$ örneklem büyüklüğünü kullanan Seong (1990)'un çalışmasıyla uyuşmamaktadır. Stone (1992)'un çalışması incelendiğinde 2 PL model altında test uzunluğunu, örneklem büyüklüğünü ve $\theta$ parametrelerinin dağılımını manipüle eden araştırmacının a parametrelerinin Bias değerleri için elde ettiği bazı bulgular bu çalışmayı desteklemektedir. Abdel-fattah (1994)'ın çalışması incelendiğinde MML kestirim yönteminin kullanıldığı analizlerde a parametresinin ortalama Bias değerlerinin karesi için test uzunluğunun 20 madde, örneklem büyüklüğünün $\mathrm{N}=1,000$ olduğu veri setinden elde ettiği sonuçlar bu çalışmayı desteklemektedir. Ancak test uzunluğunun 60 madde ve örneklem büyüklügünün $\mathrm{N}=1,000$ olduğu veri setinden elde ettiği sonuçlar bu çalışmayla tamamen çelişmektedir.

Madde güçlük (b) parametreleri için örneklem büyüklüğü sabit tutulup $(\mathrm{N}=1,000)$ yalnızca ÇK manipüle edildiğinde ortalama RMSE değerlerinde en küçük değeri standart normal dağılım verirken onu sırasıyla $C \zeta K=2,00, C \zeta K=-2,00$, $C \zeta K=-1,00$ ve $C \zeta K=1,00$ izlemiştir. $B u$ sonuç 2 parametreli normal ogive model altında 45 maddelik bir test ve N=1,000 örneklem büyüklüğünü kullanan Seong (1990)'un çalışmasıyla uyuşmamaktadır. Zwinderman ve Wollenberg (1990)'in MML ve CML kestirim yöntemlerini kullandıkları çalışmaları incelendiğinde Rasch modeli altında test uzunluğu, $\theta$ dağılımlarını ve b parametrelerinin minimum ve maksimum değerlerini manipüle eden $(-3,3$ ve $-1,1)$ araştırmacıların RMSD istatistiğinden elde ettikleri sonuçlar 1şığında şu anki çalışmadan elde edilen sonuçları desteklediği söylenemez. Stone (1992)'un çalışması incelendiğinde b parametrelerinin ortalama RMSE değerleri $\theta$ parametrelerinin farklı dağılımlarında tüm test uzunluklarında ve örneklem büyüklüklerinde birbirlerine oldukça yakındır. Ayrıca Stone (1992) çalışmasından elde ettiği b parametreleri için ortalama RMSE değerleri bu çalışmayla oldukça yakındır. Bu nedenle sonuçların şu 
anki çalışmayı desteklediği söylenebilir. Boulet (1996)'in çalışması incelendiğinde tüm örneklem büyüklükleri, test uzunlukları ve parametre kestirimi için kullanılan yazılımlarda $\mathrm{b}$ parametresi için ortalama RMSE değerleri çarpık dağılımdan standart normal dağılıma doğru küçülmektedir. Bu sonuçlar ışığında Boulet (1996)'in çalışmasının bu araştırmanın sonuçlarını desteklemediği söylenebilir. Sass vd. (2008)'in çalışması incelendiğinde b parametrelerinin kestirimi için $\theta$ parametreleri ve $b$ parametreleri standart normal dağılıma sahipken $(0,06) \theta$ parametrelerinin normal dağılmadığı ve b parametrelerinin standart normal dağglıma sahip olduğu duruma $(0,19)$ göre daha küçük RMSE değerleri elde edildiği görülebilir. Bu araştırmada da $\mathrm{b}$ parametrelerinin kestirimi için $\theta$ parametreleri standart normal dağılıma sahipken en küçük RMSE değerlerini verdiğinden Sass vd. (2008)'in çalışmasının bu araştırmayı desteklediği söylenebilir. Abdel-fattah (1994)'ın çalışması incelendiğinde MML kestirim yönteminde test uzunluğunun 20 madde ve örneklem büyüklüğünün $N=1,000$ olduğu veri setinde standart normal dağılımını $(0,143)$ diğer dağılımlardan (truncated dağılım için 0,432 ve beta dağılımı için 0,249) daha küçük MSD değerleri ürettiği görülmektedir. Test uzunluğunun 60 madde ve örneklem büyüklüğünün $\mathrm{N}=1,000$ olduğu veri seti için de aynı durum (standart normal dağılımda 0,139 , truncated dağılımda 0,263 ve beta dağılımında 0,291) geçerlidir. Bu sonuçların şu anki çalışmayı en küçük MSD değerinin standart normal dağılımdan elde edilmesi bakımından desteklediği söylenebilir. Yen (1987)'in çalışmasının test uzunluğu 20 madde olduğunda normal dağılımdan saptıkça tüm çarpık dağılımlar için RMSD değerleri büyüdüğü için LOGIST değerlerinin şu anki çalışmayı desteklediği söylenebilir. 40 maddelik test uzunluğunda ise aynı nedenden dolayı BILOG sonuçlarının bu çalışmayı desteklediği söylenebilir.

Madde güçlük (b) parametreleri için örneklem büyüklüğü sabit tutulup $(\mathrm{N}=1,000)$ yalnızca ÇK manipüle edildiğinde ortalama Bias değerlerinde sıfıra en yakın değeri standart normal dağılım verirken onu sırasıyla ÇK=2,00, ÇK=-2,00, ÇK=1,00 ve ÇK=-1,00 izlemiştir. Seong (1990)'un çalışması incelendiğinde $b$ parametreleri için prior ve posterior dağılımlar aynı ve örneklem büyüklüğü $N=1,000$ olduğu durumlardan elde edilen sonuçlar değerlendirildiğinde Bias değerlerinin birbirlerine çok yakın oldukları bu yüzden aralarındaki farkın göz ardı edilebileceği söylenebilir. Bu sonuçların yalnızca sıfıra en yakın ortalama Bias değerinin standart normal dağılımdan elde edilmesi nedeniyle bu araştırmayı desteklediği söylenebilir. Stone (1992)'un çalışması incelendiğinde test uzunluğunun 40 madde ve örneklem büyüklüğünün $\mathrm{N}=1,000$ olduğu durum dışındaki tüm veri setlerinde standart normal dağılan $\theta$ parametrelerinden elde edilen ortalama Bias değerleri diğer dağılım türlerine göre sıfıra daha yakındır. $\mathrm{Bu}$ nedenle en yakın ortalama Bias değerlerinin standart normal dağılımdan elde edilmesi şu anki çalışmayı desteklemektedir. Abdel-fattah (1994)'ın çalışması incelendiğinde MML kestirim yönteminde test uzunluğunun 20 madde ve örneklem büyüklügünün $\mathrm{N}=1,000$ olduğu veri setinde standart normal dağılımın diğer dağılımlardan sıfira daha yakın Bias değerlerinin karesini ürettiği görülmektedir. Test uzunluğunun 60 madde ve örneklem büyüklüğünün $\mathrm{N}=1,000$ olduğu veri seti için de aynı durum 
geçerlidir. Bu sonuçların sıfıra en yakın Bias değerinin standart normal dağılımdan elde edilmesi nedeniyle şu anki çalışmayı desteklediği söylenebilir.

Madde ayırt edicilik (a) parametreleri için hem örneklem büyüklüğü hem de çarpıklık katsayıları manipüle edildiğinde ortalama RMSE değerleri tüm ÇK'ler için örneklem büyüklüğü arttıkça küçülmüştür. Aynı zamanda ÇK'ler ÇK=0,00'a yaklaştıkça ortalama RMSE değerlerinde yine küçülme gözlemlenmiştir. Seong (1990)'un çalışması incelendiğinde eşleşen prior ve posterior dağılımlarında (Normal/normal, Negatif/negatif, Pozitif/pozitif) tüm $\theta$ dağılım türlerinde örneklem büyüklüğü arttıkça (N=100, 1,000) elde edilen ortalama RMSE değerleri de küçülmüştür. Bu sonuçların 1şığında Seong (1990)'un çalışmasının şu anki araştırmanın sonuçlarını desteklediği söylenebilir. Stone (1992)'un çalışması incelendiğinde tüm test uzunlukları $(10,20,40$ madde) ve $\theta$ parametrelerinin dağılımında (normal, çarpık ve basık) örneklem büyüklügündeki artışın (N=250, 500, 1,000) ortalama RMSE değerlerini düşürdüğü görülmektedir. Aynı zamanda tüm test uzunluklarında $\theta$ parametrelerinin standart normal dağılımının diğer çarpık dağılımlardan daha küçük ortalama RMSE değerleri ürettiği gözlemlenmiştir. Bu sonuçların şu anki araştırmadan elde edilen sonuçları tamamen desteklediği söylenebilir. Kieftenbeld ve Natesan (2012)'ın çalışmaları incelendiğinde MML kestirim yöntemi için tüm dağılım türlerinde (normal, çarpık ve uniform) örneklem büyüklügü arttıkça (N=75, 150, 300, 500, 1,000) elde edilen RMSE değerlerinde küçülme gözlenmektedir. Bu nedenle araştırmacıların ulaştı̆̆ sonuçların şu anki çalışmadan elde edilen sonuçları desteklediği söylenebilir. Boulet (1996)'in çalışması incelendiğinde tüm test uzunluklarında, kestirimin uygulandığı yazılım türlerinde ve $\theta$ parametrelerinin dağ 11 lım türlerinde örneklem büyüklüğü arttıkça a parametreleri için elde edilen RMSE değerlerinde küçülme gözlemlenmiştir. Bu nedenle Boulet (1996)'in çalışmasından elde edilen sonuçlar şu anki çalışmadan elde edilen sonuçlar desteklemektedir. Abdel-fattah (1994)'ın çalışması incelendiğinde elde edilen sonuçların MML kestirim yöntemi için tüm test uzunluklarında ve $\theta$ parametrelerinin dağılım türlerinde örneklem büyüklüğü arttıkça elde edilen RMSE değerlerinde küçülme gözlemlenmiştir. Bu nedenle araştırmacının çalışmasında ulaştığı sonuçların bu çalışmadan elde edilen sonuçları desteklediği söylenebilir. Akour ve AL-Omari (2013)'nin çalışmaları incelendiğinde 3 PL model altında test uzunluklarını ve örneklem büyüklüklerini manipüle etmişlerdir. Tüm test uzunluklarında a parametrelerinin ortalama RMSL değerleri örneklem büyüklüğü arttıkça küçülmüştür. Çalışmadan elde edilen bu sonuçların şu anki araştırmayı tamamen desteklediği söylenebilir.

Madde ayırt edicilik (a) parametreleri için hem örneklem büyüklüğü hem de çarpıklık katsayıları manipüle edildiğinde ortalama Bias değerleri ÇK=-2,00 ve ÇK=2,00 için örneklem büyüklügü arttıkça sıfırdan uzaklaşma, ÇK=0,00 için sıfıra yakınlaşma eğilimindedir. ÇK=-1,00 ve ÇK=1,00 için örneklem büyüklüğündeki artış ortalama Bias değerlerinde belirli şekilde sıfıra yakınlaşma ya da sıfırdan uzaklaşma göstermek yerine dalgalı bir seyir izlemiştir. Seong (1990)'un çalışması incelendiğinde prior ve posterior dağılımların eşleştiği durumlarda tüm dağılımlar için örneklem büyüklüğü arttıkça elde 
edilen ortalama Bias değerleri de sıfıra yakınlaşmıştır. Bu sonuçlar değerlendirildiğinde şu anki çalışmada kullanılan ÇK=0,00 için sonuçlar desteklenirken diğer ÇK'ler için sonuçlar desteklenmemektedir. Stone (1992)'un çalışmasından elde edilen bulgular değerlendirildiğinde şu anki çalışmayla benzer sonuçlara ulaştıkları görülebilir. Bu nedenle Stone (1992)'un çalışması bu araştırmayı desteklemektedir. Abdel-fattah (1994)'ın çalışmasından elde edilen bulgular incelendiğinde şu anki çalışmadan elde edilen sonuçların $\theta$ dağılımının türü, madde $(a, b)$ ve yetenek $(\theta)$ parametrelerinin dağılımlarının birbirlerini etkilemesi, test uzunluğunun yetersiz kalması gibi nedenlerden kaynaklandığı düşünülmekle beraber beta dağılımından oluşan veri setleri şu anki araştırmayı desteklemektedir.

Madde güçlük (b) parametreleri için hem örneklem büyüklüğü hem de ÇK manipüle edildiğinde örneklem büyüklügü arttıkça tüm ÇK'ler için ortalama RMSE değerleri beklendiği gibi küçülme eğilimindedir. Ancak $N=250$ örneklem büyüklüğü hariç diğerlerinde $C ̧ K=-2,00$ ve $C ̧ K=2,00$ olan dağılımlar ÇK=-1,00 ve ÇK=1,00 olan dağılımlardan daha küçük ortalama RMSE değerleri üretmiştir. En küçük RMSE değerleri ise tüm örneklem büyüklüklerinde $\theta$ parametreleri standart normal dağılıma sahipken elde edilmiştir. Seong (1990)'un çalışması incelendiğinde prior ve posterior dağılımların eşleştiği durumlarda tüm dağılımlarda örneklem büyüklüğü arttıkça ortalama RMSE değerlerinde küçülme gözlemlenmiştir. $\theta$ parametreleri normal dağılıma sahip veri seti incelenirken tüm örneklem büyüklüklerinde genellikle diğer dağılımlardan daha büyük ortalama RMSE değerleri elde edilmiştir. $\mathrm{Bu}$ bulgular değerlendirildiğinde Seong (1990)'un çalışmasından elde ettiği sonuçların şu anki araştırmayı desteklemediği söylenebilir. Stone (1992)'un çalışması incelendiğinde tüm test uzunlukları ve $\theta$ parametrelerinin dağılımlarında örneklem büyüklüğü arttıkça ortalama RMSE değerlerinin küçüldügü görülmektedir. Ayrıca en küçük ortalama RMSE değerleri test uzunluğunun 40 madde ve örneklem büyüklüğünün $\mathrm{N}=1,000$ olduğu veri setleri hariç her zaman $\theta$ parametreleri normal dağıldığında elde edilmiştir. Bu bulgular değerlendirildiğinde elde edilen sonuçların şu anki çalışmayı desteklediği söylenebilir. Abdel-fattah (1994)'ın çalışması incelendiğinde test uzunluğunun 20 maddeden oluştuğu ve $\theta$ parametrelerinin trucated dağılıma sahip olduğu veri seti dışındaki diğer sonuçların şu anki çalışmayı desteklediği söylenebilir. Kieftenbeld ve Natesan (2012)'ın çalışmaları incelendiğinde MML kestirim yönteminde tüm test uzunlukları ve $\theta$ parametrelerinin dağılımları için örneklem büyüklüğü arttıkça ortalama RMSE değerlerinde küçülme gözlemlenmiştir. Bu bulgular değerlendirildiğinde elde edilen sonuçların şu anki çalışmayı desteklediği söylenebilir. Boulet (1996)'in çalışması incelendiğinde $\theta$ parametrelerinin normal dağıldığı veri setleri şu anki çalışmanın normal dağılımdan elde ettiği sonuçları desteklemektedir. Çarpık dağılımın kullanıldığg veri setlerinin TESTFACT sonuçları da değerlendirildiğinde bu çalışmayı desteklediği görülmektedir. Akour ve ALOmari (2013)'nin çalışmaları incelendiğinde tüm test uzunlukları için örneklem büyüklüğü arttıkça ortalama RMSL değerlerinin küçülme gösterdiği görülmüştür. Bu bulgular değerlendirildiğinde elde edilen sonuçların şu anki çalışmayı desteklediği söylenebilir. Şahin ve Anıl (2017)'ın çalışmaları incelendiğinde elde edilen sonuçların şu anki çalışmayı desteklemediği söylenebilir. 
Madde güçlük (b) parametreleri için hem örneklem büyüklüğü hem de ÇK manipüle edildiğinde örneklem büyüklüğü arttıkça ÇK=-1,00 ve ÇK=1,00 dışında ortalama Bias değerleri beklendiği gibi sıfira yakınlaşma eğilimindedir. ÇK=-1,00 ve ÇK=1,00 olan dağglımlarda ise örneklem büyüklüğü arttıkça ortalama Bias değerleri sıfırdan uzaklaşmaktadır. Seong (1990)'un çalışması incelendiğinde prior ve posterior dağılımların eşleştiği durumlarda $\theta$ parametrelerinin tüm dağılım türlerinde örneklem büyüklüğü arttıkça ortalama Bias değerlerinin de sıfira yaklaştığı görülmektedir. Bu bulgular değerlendirildiğinde elde edilen sonuçların şu anki araştırmayı desteklemediği söylenebilir. Stone (1992)'un çalışması incelendiğinde test uzunluğunun 10 ve 40 maddeden oluşan veri setlerinden elde edilen sonuçların şu anki araştırmanın sonuçlarını desteklediği söylenebilir. Abdel-fattah (1994)'ın çalışması incelendiğinde elde edilen sonuçların şu anki çalışmayı desteklemediği söylenebilir.

Yukarıdaki tüm çalışmalar ve RMSE ile Bias sonuçları değerlendirildiğinde yalnızca $\theta$ parametreleri standart normal dağ 1 lıma sahipken ve $\mathrm{N}=2,000$ örneklem büyüklügünde madde parametre kestirim işlemi gerçekleştirmek uygun görünmektedir.

\section{KAYNAKÇA}

Abdel-fattah, A. A. (1994, Nisan). Comparing BILOG and LOGIST Estimates for Normal, Truncated Normal, and Beta Ability Distributions. Amerikan Eğitim Araştırmaları Derneği yıllık toplantısında sunulan bildiri, New Orleans, LA. (ERIC Belge Çoğaltma Servisi No. ED374158)

Akour, M. \& AL-Omari, H. (2013). Empirical Investigation of the Stability of IRT Item-Parameters Estimation. International Online Journal of Educational Sciences, 5(2), 291-301.

Boulet, J. R. (1996). The Effect of NonNormal Ability Distributions on IRT Parameter Estimation Usin FullInformation and Limited-Information Methods. (Yayımlanmamış doktora tezi). University of Ottowa/Faculty of Education, Ottowa.

Browne, M.W. \& Cudeck, R. (1993). Alternative Ways of Assessing Model Fit. Bollen, K.A. \& Long, J.S.. Testing Structural Equation Models. Newbury Park, CA:Sage kitabından

Bulut, O. \& Sünbül, Ö. (2017). Monte Carlo Simulation Studies in Item Response Theory with the R Programming Language. Eğitimde ve Psikolojide Ölçme ve Değerlendirme Dergisi, 8(3), 266-287.

Chalmers, R. P. (2012). mirt:A Multidimensional Item Response Theory Package for the R Environment. Journal of Statistical Software, 48(6), 1-29.

Crocker, L. \& Algina, J. (2008). Introduction to Classical and Modern Test Theory. Mason, Ohio: Cengage Learning.

de Ayala, R. J. (2009). The Theory and Practice of Item Response Theory. New York, NY: The Guilford Press.

DeMars. C. (2003). Sample Size and the Recovery of Nominal Response Model Item Parameters. Applied Psyhcological Measurement, 27(4), 275-288.

Drasgow, F. (1989, Mart). An Evaluation of Marginal Maximum Likelihood Estimation for the TwoParameter Logistic Model. Applied Psychological Measurement, 13(1), 77-90. 
Ebel, R. L. \& Frisbie, D. A. (1991). Essentials of Educational Measurement (5. baskl). New Delhi: PrenticeHall.

Eser, D. Ç. \& Gelbal, S. (2015). Farklı Boyutluluk Özelliklerindeki Basit ve Karmaşık Yapılı Testlerin Çok Boyutlu Madde Tepki Kuramına Dayalı Parametre Kestirimlerinin İncelenmesi. Eğitimde ve Psikolojide Ölçme ve Değerlendirme Dergisi, 6(2), 331-350.

Feinberg, R. A. \& Rubright, J. D. (2016, Haziran). Conducting Simulation Studies in Psychometrics. Educational Measurement: Issues and Practice, 35(2), 36-49.

Finch, W. H. \& French, B. F. (2019). Educational and Psychological Measurement. New York, NY: Routledge.

Harwell, M., Stone, C. A., Hsu, Tse-Chi. \& Kirişçi, L. (1996, Haziran). Monte Carlo Studies in Item Response Theory. Applied Psychological Measurement, 20(2), 101-125.

Hulin, C. L., Lissak, R. I. \& Drasgow, F. (1982). Recovery of Two- and Three-Parameter Logistic Item Characteristic Curves: A Monte Carlo Study. Applied Psychological Measurement, 6(3), 249-260.

Karadavut, T. (2017). Estimation of Item Response Theory Models When Ability is Uniformly Distributed. The Eurasia Proceedings of Educational and Social Science, 7(), 30-37.

Kieftenbeld, V. \& Natesan, P. (2012). Recovery of Graded Response Model Parameters: A Comparison of Marginal Maximum Likelihood and Markov Chain Monte Carlo Estimation. Applied Psychological Measurement, 36(5), 399-419.

Lord, F. M. (1968). An Analysis of the Verbal Scholastic Aptitude Test Using Birnbaum's Three-Parameter Logistic Model. Educational and Psychological Measurement, 28(4), 989-1020.

Lord, F. M. \& Novic, M. R. (2008). Statistical Theories of Mental Test Scores. USA: Information Age Publishing.

Luecht, R. \& Ackerman, T. A. (2018, Ocak). A Technical Note on IRT Simulation Studies: Dealing With Truth, Estimates, Observed Data, and Residuals. Educational Measurement: Issues and Practice, 37(3), 65-76.

Marso, R. N. \& Pigge, F. L. (1988, Nisan). An Analysis of Teacher-Made Tests: Testing Practices, Cognitive Demands, and Item Construction Errors. Ulusal Ĕ̈itimde Ölçme Kurulu (NCME) Yıllık Toplantısında sunulmuş bildiri, New Orleans, LA.

Meyers, L. S. \& Grossen, N. E. (1974). Behavioral Science: Theory, Procedure, and Design. USA: W. H. Freeman and Company.

Olmuş, H., Nazman, E. \& Erbaş, S. (2016). An Evaluation of the Two Parameter (2-PL) IRT Models Through a Simulation Study. Gazi University Journal of Science, 30(1), 235-249.

Reise, S. P. \& Yu, J. (1990). Parameter Recovery in the Graded Response Model Using MULTILOG. Journal of Educational Measurement, 27(2), 133-144.

Sass, D. A., Schmitt, T. A. \& Walker, C. M. (2008, Nisan). Estimating Non-Normal Latent Trait Distributions within Item Response Theory Using True and Estimated Item Parameters. Applied Measurement in Education, 21(1), 65-88.

Seong, Tae-Je. (1990, Eylül). Sensitivity of Marginal Maximum Likelihood Estimation of Item and Ability Parameters to the Characteristics of the Prior Ability Distributions. Applied Psychological Measurement, 14(3), 299-311. 
Stone, C. A. (1992, Mart). Recovery of Marginal Maximum Likelihood Estimates in the Two-Parameter Logistic Response Model: An Evaluation of MULTILOG. Applied Psychological Measurement, 16(1), 1-16.

Sünbül, Ö. \& Bulut, O. (2017). Monte Carlo Simulation Studies in Item Response Theory with the R Programming Language. Eğitimde ve Psikolojide Ölçme ve Değerlendirme Dergisi, 8(3), 266-287.

Swaminathan, H. \& Gifford, J. A. (Nisan,1979). Estimation of Parameters in the Three-Parameter Latent Trait Model. Amerikan Eğitim Araştırmaları Birliği (AERA) ve Ulusal Ĕgitimde Ölçme Kurulu (NCME)'nun düzenlediği "Pratik Ölçme Sorunlarını Çözme Aracı Olarak Gizil Özellikler Modellerinin Keşfi (Explorations of Latent Trait Models as a Means of Solving Practical Measurement Problems)" başlıklı sempozyumda sunulmuş bildiri, San Francisco, CA.

Şahin, A. \& Anıl, D. (2017). The Effects of Test Length and Sample Size on Item Parameters in Item Response Theory. Educational Science: Theory \& Practice, 17(1), 321-335.

Turgut, M. F. \& Baykul, Y. (2015). Eğitimde Ölçme ve Değerlendirme (7.baskl). Ankara: Pegem Akademi.

Uysal, İ., Ertuna, L., Ertaş, F. G. \& Kelecioğlu, H. (2019). Performance Based on Ability Estimation of the Methods of Detecting Differential Item Functioning: A Simulation Study. Eğitimde ve Psikolojide Ölçme ve Değerlendirme Dergisi, 10(2), 133-148.

Yen, W. M. (1987, Haziran). A Comparison of the Efficiency and Accuracy of BILOG and LOGIST. Psychometrika, 52(2), 275-291.

Yıldırım, Y. (2015). Derecelendirilmiş Tepki Modeli Temelli Parametre Kestiriminde Normalliğin İhlalinin Ölçme Kesinliğine Etkisi. Yüksek Lisans Tezi, Gazi Üniversitesi Eğitim Bilimleri Enstitüsü, Ankara.

Zwinderman, A. H. \& van den Wollenberg, A. L. (1990). Robustness of Marginal Maximum Likelihood Estimation in the Rasch Model. Applied Psychological Measurement, 14(1), 73-81. 